\title{
Globalisation and Models of State: Debates and Evidence from Ireland
}

\author{
Peadar Kirby* and Mary Murphy** \\ * Department of Politics and Public Administration, University of Limerick (UL) \\ ** Department of Sociology, National University of Ireland Maynooth (NUIM)
}

Ireland's economic boom from 1994 to 2000 (widely labeled the 'Celtic Tiger') has been seen by analysts as indicating the country's success in benefiting from the opportunities offered by globalisation. ${ }^{1}$ While an initial reading emphasised that economic transformation had been achieved through market liberalisation, ${ }^{2}$ this was soon contested by a literature that focused more on the crucial role played by the state. Scholars at the influential Economic and Social Research Institute (ESRI) argued that 'there was a great deal more to Ireland's success than liberalization of markets. The state has been deeply implicated in the entire process, managing both economic development and the welfare state' ${ }^{3}$. They conclude that 'it is not a simple story of globalization, forced withdrawal of the state and the promotion of neo-liberalism' ${ }^{4}$. Examining in more detail the role played by the Irish state, Ó Riain characterised it as a 'flexible developmental state' in contrast to the bureaucratic developmental states of East Asia, arguing that this constitutes a new model of state-led development that is more responsive to the demands and pressures of globalisation. ${ }^{5}$

Kirby introduced the concept of competition state to the Irish literature, arguing that it describes more accurately the nature and operation of the Irish state in the era of the Celtic Tiger since it prioritises goals of economic competitiveness over those of social cohesion and welfare. ${ }^{6}$ Following Kirby, Dukelow also adopts the concept of competition state for the Irish case as 'the state has taken a selective interventionist role in the manner of a competition state to re-orient social security policy to enhance economic competitiveness by tackling unemployment, yet leaving levels of income inequality and poverty remain relatively high'. exemplar of the competition state, where social policy is subordinated to the needs of the economy'. 8

These debates on the role of the state in Ireland's adaptation to globalisation echo and draw upon wider debates on how the state is changing under the impact of global market pressures. ${ }^{9}$ Yet, these debates have also been faulted for being conducted at too generalised and abstract a level, lacking a base in empirical study. Hay has written that 'the ethereal realms of abstraction at which the analysis is for the most part conducted are not densely populated with clearly identifiable actors, strategic or otherwise'. ${ }^{10}$ Phillips echoes and advances this critique, identifying economism (namely a concentration on state economic policy and strategies) and a functionalist bias (namely understanding the form of state as an outcome of its adaptation to the challenges of economic globalisation) as characterising these approaches. This bias, according to Phillips, results in a 
'generalized failure to consider or advance clear understandings of the processes by which outcomes are produced' so that politics, in the sense of 'variation, contingency and specificity in the institutional structures of states, the nature of state strategies and the types of state-society linkages that prevail in particular political economies' is largely missing. ${ }^{11}$

This article seeks to address these weaknesses through analysing the Irish state both theoretically and empirically. Taking as its starting point the debates on characterising the Irish state as either a form of developmental state or as a competition state, ${ }^{12}$ the article begins by defining the two terms as used in the Irish debate and discussing the differences between them. The following section elaborates a methodology through which to test what are essentially hypotheses about the Irish state, through an examination of the changing nature of social security policy. Section three undertakes the empirical examination of how and why policy in this area has changed while the fourth section draws out the implications of this empirical study both for the hypotheses on the nature of the Irish state. The final section draws conclusions.

\section{Developmental state or competition state?}

Understanding the institutional underpinnings of the Celtic Tiger, therefore, has given rise to two competing conceptions of the state. Is the contemporary Irish state a new type of developmental state, thereby holding lessons of successful development for many other states, or is it a competition state, an exemplar of how globalisation resituates the state so that it prioritises the needs of global capital over those of its own citizens?

\section{Developmental state}

Characterisations of the Irish state as developmental take as their starting point the literature that developed in the 1980s out of analyses of the role of the East Asian state in that region's developmental success and which elaborated the concept of the 'developmental state'. ${ }^{13}$ In applying the concept of 'embedded autonomy' taken from Evans $^{14}$ to the Irish state, Ó Riain characterised the Irish state as a 'flexible developmental state' in contrast to the bureaucratic developmental states of East Asia, arguing that this constitutes a new model of state-led development that is more responsive to the demands and pressures of globalisation. ${ }^{15}$ His later work slightly amended the concept to that of a Developmental Network State (DNS) as 'network centrality is critical to this new state - isolation from the local or the global renders it ineffective'. ${ }^{16}$ The concept of the developmental state was adopted by the National Economic and Social Council (NESC) in its 2003 tri-annual statement of the state's economic and social strategy and used as the basis for proposing a Developmental Welfare State (DWS) for Ireland. ${ }^{17}$

Central to the concept of the developmental state is the concept of capacity. With Skocpol, we can define state capacity as the ability of the state to pursue and/or implement official goals. ${ }^{18}$ Much discussion of states presupposes such a capacity; however, as Weiss reminds us, 'states are not uniformly capable across all policy areas, ${ }^{19}$ and she quotes Krasner's telling point that needs to be borne centrally in mind in any analysis of the capacity of today's Irish state: 
There is no reason to assume a priori that the pattern of strengths and weaknesses will be the same for all policies. One state may be unable to alter the structure of its medical system but be able to construct an efficient transportation network, while another can deal relatively easily with getting its citizens around but cannot get their illness cured. ${ }^{20}$

State capacity is therefore a more complex concept than is often acknowledged. Capacity (or its absence) may derive from organisational competencies within states (quality of the public service, organisational synergies and efficiencies, resources sufficient to achieve goals), from the social relations within which states are embedded (autonomy from vested interest groups is a major theme in the literature yet, in Evans's view, it needs to be combined with an embeddedness in civil society so that the state serves social goals), or from the challenges posed by the external environment to the action of states (this theme looms large in the literature on globalisation). Synergies may be achieved between these different elements that account for final outcomes but, more often than not, capacity can be very unevenly spread across the complex institutional configurations that constitute states. Indeed, for Evans et al.: 'The very unevenness of a State's existing capacities ... may be the most important structural feature to recognise in understanding how it confronts challenge' ${ }^{21}$ Such a focus characterises Ó Riain's work on the Irish state. His claim of developmental success rests on equating successful development with the generation of some successful industrial sectors. Acknowledging the pressures and opportunities of globalisation, Ó Riain labels his concept the developmental network state to take account of 'the multiple embeddedness of state agencies in professional-led networks of innovation and in international capital, as well as by the state's networked organizational structure' ${ }^{22}$ However, he immediately acknowledges that 'these multiple state-society alliances lead to uneven internationalization of society and growing inequality, generating political tensions with which the fragmented state structure cannot deal effectively, ${ }^{23}$ Unevenness therefore is central to his concept of the Irish state. ${ }^{24}$

Yet, a reminder of the uneven nature of states' capacity needs to be balanced by a recognition of the overarching capacity of states to achieve outcomes that are fundamentally transformative of the economy and of society. This finds expression in the literature on the developmental state and presupposes, if not unified action by states, at least the ability to follow a coherent project and to implement it with some success. It is this recognition that focuses attention on the need to identify the central logic of a state's actions. For Weiss (as for most of the literature on the developmental state and for Ó Riain in the Irish case), the focus is on the state's capabilities in the industrial economy: 'transformative capacity in this sense refers to the ability of a state to adapt to external shocks and pressures by generating ever-new means of governing the process of industrial change'. ${ }^{25}$ Yet, Weiss goes on to distinguish transformative capacity in the industrial sphere from distributive states or 'dual' states like Germany and Japan that 'combine both developmental and distributive capabilities - in short, growth with equity'. These latter, she adds, 'may have more long-run potential'. ${ }^{26}$ This reading of state capacity therefore focuses not on policy tools, regime characteristics or class structure (which might account for the unevenness in capacity in different parts of a particular 
state) but rather on the distinctive organisational complexes that characterise the varieties of capitalism literature ${ }^{27}$ as well as on the developmental projects that these states pursue. Beyond the unevenness therefore, a certain unifying logic is identified as characterising those most successful and sustainable states centred on a common transformative purpose to both economic and social policy.

\section{Competition state}

Whereas the developmental state concept emerged from analysing the ways in which certain developing states (in East Asia and in Latin America) succeeded in building a modern and competitive industrial economy, the competition state concept emerged from analysing the ways in which developed industrial states were restructuring themselves in response to the constraints and opportunities opened up by neoliberal globalisation in the 1990s. While initially under pressure from internal causes such as recession and the fiscal pressures on welfare spending, by the 1980s and 1990s, welfare states were also under pressure from outside factors such as international competitiveness, the mobility of capital worldwide and intensified international trade ${ }^{28}$. A central cause of these pressures has been the impact of new information and communications technologies (ICTs). These have made possible both the more intense and immediate global interconnectedness that drives finance, production and trade and also new forms of corporate organisation that have come to dominate more and more key production chains worldwide, thereby strengthening the power of global market forces as against that of national state authorities. As Ruggie has recognised, the globalisation of financial markets and production chains challenged the premises on which the grand bargain between capital and labour rested since that bargain presupposed a world in which the state could effectively mediate external impacts through such tools as tariffs and exchange rates. ${ }^{29}$ In this situation, welfare states have not collapsed in the way that some communist and developing states did but they are under pressure to reduce costs and erode the level and extent of protection they previously provided. ${ }^{30}$ This global context, therefore, has created new pressures to which all states have to respond. It is out of analysing the ways in which states are responding that the concept of the competition state emerged.

Various attempts have been made to characterise the new regime that is emerging as a successor to the Keynesian welfare state. Jessop sees this 'new state form' as a Schumpeterian workfare state (SWS) which seeks 'to strengthen as far as possible the structural competitiveness of the national economy by intervening on the supply-side; and to subordinate social policy to the needs of labour market flexibility and/or to the constraints of international competition ${ }^{31}$ In his work, Cerny describes the emergence of a 'competition state' out of the tensions between the demands of economic globalisation and the embedded state/society practices that characterised the national welfare state as the priorities of policy move away from the general maximisation of public welfare (full employment, redistributive transfer payments and social service provision) to the promotion of enterprise, innovation and profitability in both private and public sectors. These reactions, however, follow no set pattern or master plan: 'The emerging embedded neoliberal consensus is therefore not simply a developing "from outside" or "from above"; it is also a political construction promoted by political entrepreneurs who must 
design projects, convince others, build coalitions and ultimately win some sort of political legitimacy "from inside" and "from below", 32

Tracing this process as they see it happening in western European states and the European Union itself, in North America and New Zealand, in Latin America and in eastern European countries, Cerny et al. identify a process that is 'almost without exception elite-driven .... based on sustained support from converted academics, policy advisers and consultants both within and outside the public sector, government officials, and firms and other economic actors, especially representatives of employers and business organisations, and, especially consumers and many taxpayers'. ${ }^{33}$ What can be observed, therefore, 'is not so much the continuity or maintenance of older "varieties of capitalism", but rather the emergence of varieties of neoliberalism - of diversity within convergence, of the forging of different "roads to globalisation". ... States are increasingly becoming "competition states", 34 This belies any easy claim that the state is retreating or that its role is marginalised in the political economy of today's globalised world order. Rather, what is happening is the redefinition of its core activities as it adapts to the new global environment in which it operates. This helps make sense of what otherwise may seem a contradiction between the state's ever weakening ability to secure the welfare of its citizens while on the other hand it becomes ever more intrusive in the life of the national economy such as, for example, through a myriad of new regulatory agencies. As they point out: 'Deregulation was never really deregulation; it increasingly became the replacement of outcome-orientated and discretionary interventionism with new market friendly regulations - a form of pro-market re-regulation. Indeed, in many cases the new regulations were more complex and onerous than the old type. A well known example is that of insider trading regulation in financial markets, almost unknown (except in the US) before the 1980s'. ${ }^{35}$

These two conceptions of the state therefore have some common features but differ in a number of crucial ways. Perhaps most significantly, both agree that the state can make a difference though, perhaps echoing their different origins, the competition state concept recognises more fully the constraints placed on state actions by the competitive pressures of today's globalisation. Both acknowledge the uneven nature of state actions, though both also claim that a central overarching logic can be identified behind this unevenness. It is the nature of this overarching logic that constitutes the key difference as developmental state theorists claim that such states possess the capacity to achieve outcomes that fundamentally transform the economy and society towards higher levels of development. Competition state theorists, on the other hand, identify a logic that moves state actions away from the maximisation of welfare towards the promotion of enterprise and profitability as national elites respond to the pressures of globalisation. Theorists of both concepts recognise that both developmental and competition states do not confirm to uniform models but reflect the internal political configurations and culture through which the overarching logic of developmentalism or competition is mediated, though it must be said that both literatures have paid insufficient attention to the politics through which these logics emerge and come to dominance. 
Where there is less clarity about the differences between both concepts concerns the possibilities for more progressive forms of both types of state. Cerny et al. recognise that neoliberal public policies 'do not merely constrain but also bring opportunities. Contemporary politics entails both a process of choosing between different versions of neoliberalism and the attempt to innovate creatively within the new neoliberal playing field'. ${ }^{36}$ One expression of these possibilities is the emergence of a social neoliberalism, they state. ${ }^{37}$ Ó Riain criticises the competition state concept for obscuring 'the existence of a political space for struggles within and through existing institutions over how development could and should be structured' as it ignores 'the many political possibilities that the institutions of economic development present for future transformation'. ${ }^{38}$ What here distinguishes proponents of each of the concepts is the potential for transformation that exists. For, as made clear above, competition state theorists also recognise that politics matters and that it results in different outcomes in different states - 'different versions of neoliberalism'. Ó Riain goes further in claiming that spaces exist for going beyond neoliberalism to social democracy and his book ends by outlining what this might entail. ${ }^{39}$ Here again what is at issue is more empirical than theoretical: Cerny et al. outline at some length the erosion of the basis for a social democratic alternative as it is happening in practice in many parts of the world whereas Ó Riain's account is limited to a purely theoretical outline of what such an alternative might look like while neglecting the political or social bases for its emergence. On the contrary, he acknowledges that the developmental state 'will face an increasingly contentious politics of national inequality because unequal integration into the globalisation project undermines solidaristic national social contracts'; however, he fails to address how it might overcome these to build a more social democratic alternative. ${ }^{40}$ From these accounts therefore a lack of clarity lingers as to whether, through progressive political actions, both the competition and the developmental states could come increasingly to resemble one another. Indeed, Cerny has equated the East Asian developmental states with competition states. ${ }^{41}$ Yet, it does appear that a fundamental difference still distinguishes Cerny's social neoliberalism from Ó Riain's social democratic developmentalism with the latter entailing a much stronger version of governing or restraining the market whereas the former is posited on a benign market to which the state plays a supporting role.

\section{Testing hypotheses}

As outlined in the previous section, both the developmental state and a competition state remain hypotheses to be tested. This is one objective of this article. Accepting the critiques of Hay and Phillips as outlined earlier, it does so in order to take the debate from the 'ethereal realms of abstraction' ${ }^{42}$ and to devote attention to 'variation, contingency and specificity in the institutional structures of states, the nature of state strategies and the types of state-society linkages that prevail in particular political economies', as Phillips put it. ${ }^{43}$ It does this through examining the logic of policy in the Irish state, seeking to identify if this follows a developmental or a competitive logic. Again following from Phillips's critique of economism in the literature, it chooses the area of social policy as this has tended to be neglected by proponents of the developmental state. This section outlines a methodology through which both conceptions of the state will be tested. 
While Ó Riain acknowledges the unevenness evident in the actions of Ireland's networked developmental state, its claim to be developmental rests on its transformative capacity. Evans, on whose concept of embedded autonomy Ó Riain bases his theory, places a lot of emphasis on the need for the state to be encompassing and coherent, reconciling conflicting interests, immersed in a dense network of ties that bind it to societal allies with transformational goals. Evans writes: 'The state's corporate coherence enhances the cohesiveness of external networks and helps groups that share its vision overcome their own collective action problems. Just as predatory states deliberately disorganize society, developmental states help organize it'. ${ }^{44}$ Beyond the uneven capacity which is a feature of all states, an encompassing logic of developmentalism is therefore seen to characterise those states most successful at developing the ability to adapt to fast changing external circumstances and challenges. This logic, then, becomes the crucial criterion for judging whether the Irish state is developmental.

Turning to the competition state, Cerny identifies what clearly distinguishes the competition state when he writes that 'liberalization, deregulation, and privatization have not reduced the role of state intervention overall, just shifted it from decommodifying bureaucracies to marketizing ones' ${ }^{45}$ Referring to various areas of policy such as industrial policy, trade policy and social policy, he adds that 'in all these settings, the state is no longer able to act as a decommodifying hierarchy (i.e., taking economic activities out of the market). It must act more and more as a collective commodifying agent (i.e., putting activities into the market) and even as a market actor itself. ${ }^{46}$ Commodification therefore becomes the criterion for judging whether the Irish state is a competition state.

A major weakness of competition state theory is that it has been developed largely in the abstract, with little empirical application or testing. Since the competition state prioritises economic competitiveness over social cohesion and welfare through subordinating the latter to the logic of the former, it follows that empirical examination of how Ireland's social security regime has changed over the past two decades offers evidence to test the applicability of the competition state to Ireland. This period is chosen as it coincides with the transformation of the Irish economy: the turnaround in state policy that laid the foundations for the Celtic Tiger is usually dated to the actions of the incoming Fianna Fáil government of 1987. An examination of the changing nature of social security policy over this period will serve to test whether the Irish state is following a wider logic of developmental transformation, or whether this is limited to spheres such as industrial upgrading but not generalised as a feature of state policy.

Five indicators of social security recommodification are elaborated and examined in turn - regulation, retrenchment, residualisation, activation/conditionality and defamilarisation. These indicators allow an analysis of how the role of the state has shifted over the period in question, whether fiscal policy has become more neo-liberal and has resulted in greater vulnerability and inequality, and the extent of reliance on the market to provide public and private goods. These indicators would also be applicable to other areas of policy like health, housing or education. Testing each indicator highlights where Irish social security policy is consistent with or deviates from movement towards a competition state. On the 
other hand a general review of the scale and scope of policy change in each area also presents an opportunity to test for evidence of a transformative process of development in social security policy. The characteristics of each of the indicators can be described as follows:

- Regulation: The function of the state changes. New public management regulatory frameworks enable governments 'to steer but not row'. ${ }^{47}$ New forms of governance lead to the delegation of policy to new actors at national and other levels. This empowers business and professional technical elites. Privatisation of provision occurs either directly or by organising public service delivery around commercial or market consumer principles.

- Retrenchment: The prioritisation of international competitiveness results in a 'low tax, low inflation' fiscal policy as expressed and supervised in the EU's Growth and Stability Pact. Fiscal pressures lead countries to resort to short-term cost cutting and long-term cost containment and cost avoidance.

- Residualisation:. The focus on maintaining low welfare rates to promote work incentives has inegalitarian implications for those who cannot exercise employment routes out of poverty. Non-labour market participants including the elderly, people with disabilities and those involved in 'caring' duties at home are more vulnerable in the increasing relative gulf between the rich and poor.

- Activation/conditionality: Passive income maintenance shifts to active spending on training and education. Welfare is reinvented into 'workfare' where income support is more conditional and linked to obligations to participate in the labour market. Positive encouragement coexists with punitive sanctions.

- Defamiliarisation The quality of women's employment will be determined by the degree of individualisation of social security, access to quality education and training and sufficient investment in appropriate and affordable childcare and/or family-leave arrangements. The increased labour-market participation of women commodifies caring functions.

How each of these indicators applies to the Irish case is now reviewed in turn. If policy is found to conform to these indicators it will constitute proof of a competition state logic dominating policy whereas if these indicators are found not to apply or to apply only weakly, and if a more socially transformative logic is seen to guide state actions, then this will constitute evidence of a developmental logic governing state actions.

\section{Changing nature of Ireland's social security policy}

Regulation

Both concepts stress the transformation of the role of the state and changes in the nature of governance. Here we examine trends in regulation to identify the extent to which, in Ireland's social security policy, power has shifted to international capital and business, services have been privatised and new public management practices have been introduced.

A regulatory state 'should provide a working framework of rules and performance indicators or targets for market actors to follow, ${ }^{48}$. Historically Ireland has been a mixed 
economy welfare state but social security has been almost exclusively a statutory responsibility. Over the past two decades the state has made some attempts to divest itself of social security responsibility and so follow a more regulatory path. Since 1991 the state promoted the social inclusion role of the non-profit private sector with, first, local Area-Based Partnerships and, since 1994, employment support functions including the Local Employment Service have been delegated to local non statutory agencies. ${ }^{49} \mathrm{~A}$ 1999 White Paper promoted regulation of the community and voluntary sector and NESC and NESF documents in 2005 and 2006 respectively ${ }^{50}$ signalled a shift to service contracts requiring a new model of governance for third-sector organisations where the role of the state moves away from the provision of services to 'a regulator of rights and standards and enabler of local activist networks'. ${ }^{51}$ However the scale and scope of transformative change has not reflected the ambitious rhetoric. A further but failed example of the state's attempt to divest itself of its traditional social protection role was when a proposal to transfer disability protection to employers was blocked by the veto power of employers in both 1988 and 1992. This contrasts with the British experience where the state was able to transfer this function to private business. Irish government is more vulnerable to veto players blocking policy and is less able to divest itself of, or transform, social protection functions.

The needs and power of capital have become key drivers of social security policy. Employers and business work in a political advocacy coalition with two key government Departments (Finance, and Enterprise, Trade and Employment). The needs of international companies are facilitated by allowing them refocus social protection into private 'packages' of market-led social security provision that fundamentally alter how workers perceive the context and choices around work-related social provision. Such transformation is facilitated but not led by the state. International organisations are becoming more pivotal through processes like the EU procurement process which obliges tendering, to private and public bodies, of delivery services previously monopolised by statutory bodies (for example contracts for social security postal delivery). The state resists rather than promotes this transformation of policy. There is more overlap between domestic and international policy coalitions, particularly in the EU Open Method of Coordination covering employment policy, social inclusion and pensions policy, and more regular policy dialogue with the OECD. In this merged public/private and national/international space, the emergence in Ireland of a professional technical elite can be identified whose members engage in coordinative discourse at one remove from the political realm. Changing governance means more than a simple delegation of tasks, as renegotiation of the relationship between the private and public spheres involves a shift in power. Perhaps the clearest example is the government invitation to the private pension industry to chair the National Pensions Board. It is no coincidence to see a private, business-led style of governance result in promoting the commodification or privatisation of pensions. Strongly advocated by the international financial services sector, the Pensions (Amendment) Act 2002 introduced second-tier private Pension Savings Retirement Accounts. This policy was chosen in spite of opposition from civil servant advisors (disempowered by the power shifts inherent in this new forms of governance). International and national private-sector pressures allied to sectors of the state drove the 
dynamic behind these moves. The international context was the World Bank's promotion of a privatisation agenda in pension policy.

Managerialism is evident in Irish social policy. Consumerism, choice and new public management discourse are evident in the Strategic Management Initiative and Public Services Management Act (1997) and initiatives like 'customer service plans', 'customer service targets', and 'service delivery models' abound. A process of 'expenditure reviews' emphasising value for money has had some impact on policy development; however there is considerable resistance to new public management practices and institutional change in the Irish public service ${ }^{52}$. The capacity of a strong centralised bureaucracy to resist change is reinforced by the strength of public sector trade unions to veto change. We can conclude that there is strong evidence of the state engaging in a new public management ethos of customer-focused delivery but it remains to be seen whether such engagement has fundamentally transformed staff and claimant experience of social security delivery and whether in this instance the state has the power to transform public service delivery. Overall, then, in terms of the changing nature of regulation, there is little evidence of a transformative developmental logic behind such policy change.

\section{Retrenchment}

In a competition state we would expect a low-tax development model to necessitate budgetary constraint and cost containment measures whereas a developmental logic would lead one to expect more generous state investment in the development of services during a period of economic boom. In the Irish context two factors are worth highlighting. One factor is path dependency. Cerny's 'competition state' emerges out of the tensions between the demands of economic globalisation and the embedded state/society practices that characterised the national welfare state. However the Irish welfare state was never as deeply embedded as older social democratic or conservative welfare states and never fully aspired to the general maximisation of public welfare. In a liberal residual welfare state with a high degree of reliance on means-tested payments, there is little room to reduce already ungenerous payments. The second factor is Ireland's exceptional economic performance. Ireland's high economic growth rates and limited pressures from an ageing population means that from the mid 1990s to the mid 2000s, Ireland not only suffered less fiscal pressure than did other OECD countries but had budget surpluses and the capacity to expand social security rates and coverage. That such expansion did not happen is as much part of the story as what actually happened. The period has been described as a missed opportunity. The Irish story is one of arrested development where government abstained from using the fruits of economic growth to expand and improve social protection to the degree that might have been anticipated in a period of economic growth. ${ }^{53}$ In other word despite the fiscal capacity to be truly transformative the Irish government chose to leave the social security system largely intact and unchanged.

It is possible to review retrenchment experience not only from the perspective of shortterm cost cutting but also longer-term cost containment and cost avoidance. Ireland experienced significant social insurance retrenchment in the last 20 years, but less retrenchment of social assistance payments. Two sets of social security cuts, the 1992 
'Dirty Dozen' and the 2003 'Savage Sixteen' can be characterised as short-term responses to periods of particularly tight fiscal austerity (the 1992 EMU preparations and the post 9/11 recession in 2002-03). The period cannot be characterised as one of significant retrenchment or budgetary transformation. ${ }^{54}$ Many cuts, such as the 1994 child-income support reforms which froze the monetary value of means-tested childdependant allowances, reflect policy restructuring motivated by work incentives rather than fiscal pressures. ${ }^{55}$ Subsequent policy processes advising the restructuring of child income supports have not resulted in policy change.

Less obvious long-term cost-containment policies have had a more serious impact on Irish society. The Department of Finance, with its concern for controlling expenditure, dominates the setting of social security rates. Proposals in 1998 for a pensions adequacy benchmark and in 2001 for an adequacy benchmark for the lowest social assistance payments $^{56}$ were rejected by an advocacy coalition of the Department of Finance, employers' representatives and the Department of Enterprise and Employment. They were motivated by a combination of future cost containment, maintenance of work incentives and ensuring a level of flexibility considered essential to adapt to the global economy. More puzzling in the Irish case is the failure in the early 1990s to index earned income disregards. ${ }^{57}$ Freezing income disregards makes work incentive policy less effective and is inconsistent with a productivist-focused competition state. Such deviation is more likely explained by a cost-fixated Department of Finance dominating annual budget negotiations than by any developmental logic.

As well as cost containment there has been significant 'cost avoidance' or resistance to accommodate new social risks through the social security system. The failure to accommodate gender-related reform is discussed later. Cost avoidance can also be seen in policy responses to inflows of asylum seekers and migrant workers. State policy is to exclude these needs from Irish social security. In 1999 asylum seekers were restricted to 'direct provision' welfare entitlement. The May 2004 restriction of welfare entitlement to 'habitual residents' left migrants at the mercy of the market. As a result of direct lobbying from international companies, legislation was introduced to exempt certain non-EU migrant workers from social insurance coverage. Social security policy is therefore actively responding to the needs and desires of international capital rather than to international labour. Rather than social policy transforming to meet the needs implied by new social risks in a more global economy, the state has failed to respond to new needs or to transform social policy to meet global risks.

\section{Residualisation}

Competition state theory anticipates new forms of inequality, increased gaps between rich and poor and that those most distant from the labour market (older people, carers, women in the home, lone parents and people with disabilities) will suffer most poverty. A defining characteristic of the developmental state, by contrast, has been growing social equality. Here we review Irish trends towards more use of targeted means-tested payments, resulting in increased relative poverty and shifts in the risk of relative poverty. 
Because 'Ireland is exceptional within the EU for the high proportion of its social spending which is means tested, 58 there has been less shifting from universal to selective social security payments than one might otherwise expect in a competition state. ${ }^{59}$ This path dependency is reinforced by the NESC recommendation that Ireland maintain this hybrid model and reliance on means-tested payments ${ }^{60}$. Despite employment growth and decreases in unemployment, levels of dependency on social welfare among the working aged have not been transformed but remain stubbornly high. ${ }^{61}$ High dependency on means-tested payments might not matter if payments were adequate. However, Irish policy has always stressed work incentives and low replacement rates. As NESC rightly observes, a more transformative or developmental social policy would seek to increase welfare generosity. ${ }^{62}$ However rates, which have always been characterised by a minimal subsistence type of support, have in fact further declined relative to average net earnings. $^{63}$

Inequality is expected to rise in a competition state and to fall in a developmental state. There is evidence of a widening of income inequality in Ireland over the course of the economic boom. Between 1994 and 2005, the poorest ten per cent's share of national income decreased by 0.6 per cent and the richest ten per cent increased by 1.2 per cent. While, in 1994, 15.6 per cent lived below the 60 percent poverty line, by 200518.5 per cent lived below the same line compared to the EU average of 15 per cent. ${ }^{64}$ Other measures of income inequality such as the S80/20 and the Gini coefficient remained stable over this period at 5 and .33 respectively. As Whelan and Layte put it, the Irish state 'has not prioritised equity as an objective' and has made 'no concerted attempt to equalise incomes through taxation and redistribution'. ${ }^{65}$ Such persistence (and on some measures worsening) of inequality is neither transformational nor developmental. Nor is such inequality a question of lack of capacity. Rather it confirms the political choice to follow the central logic of a competition state and keep welfare relatively ungenerous in order to preserve work incentives.

There has also been a shift in the composition of groups experiencing relative poverty. Consistent with what would be expected under a competition state, those outside the labour market experience a higher risk of poverty. Unemployment, while still significant, is no longer the major risk factor; these at greatest risk, people with disabilities, found their rate increased by 24 per cent from 1994 to 2003 and these are closely followed by the aged and people in home duties/lone parents (respectively up 23 and 16 per cent over the same period). Consistent with competition state theory on the working poor, those in work experienced a 6 per cent increased risk of poverty in the same period. ${ }^{66}$ The trend is clear. Those relying primarily on social welfare, particularly those in receipt of social assistance means-tested payments, are most likely to fall below poverty lines linked to average incomes. ${ }^{67}$ There has been little transformation of their lives relative to the degree of change in overall incomes during the Celtic Tiger period.

\section{Activation/Conditionality}

The traditional principle of designing social security to preserve work incentives is now underpinned by a new Irish focus on 'performative inclusion', which stresses employment as the best route out of poverty. ${ }^{68}$ This policy direction is reinforced through 
both employment support services and activation policies. ${ }^{69}$ This section seeks to establish the particular style and scale of Irish commodification by reviewing three key trends: spending on active measures, changes in 'conditionality' and extension of activation beyond unemployed claimants. If Irish social policy rhetoric is translated into policy, it is here that we might expect to find significant transformation of social policy towards more active policy.

In the competition state we expect public investment to shift to active labour market spending. Significant active labour market expenditure is a long-standing feature of the Irish welfare state ${ }^{70}$ and Irish spending on active labour market programmes increased from an already comparatively high 1.46 per cent of GDP in 1985 to 1.53 percent of GDP in 2000 (a significant real spending increase). Active labour market programmes, administered by a number of government departments, have been criticised for a lack of focus on progression to employment. ${ }^{71}$ Boyle explains this as an outcome of strong advocacy coalitions, including backbench politicians, supporting the social-policy rather than the labour-market aspect of programmes. ${ }^{72}$ While, over time, programmes have become more progression oriented and linked to participation obligations, there is still scant evidence of the level of transformational institutional reform of either employment serices or income support offices experienced across most OECD countries.

Irish social security literature is ambiguous about whether Irish policy moved towards more work obligations. McCashin, Van Oorschot, Boyle, Ó Riain and O’Connell, Daly and Yeates, Martin and Grubb and Pearson ${ }^{73}$ all conclude that compulsion is remarkably absent in the Irish policy regime relative to more conditional practice in both liberal regimes and small open economies. Empirical evidence supports Taylor's and Dukelow's conclusions that policy shows significant supportive and punitive changes which, combined, have pushed or pulled welfare claimants towards employment. ${ }^{74}$ This stronger style of commodification, 'systematic engagement', was introduced in the 1997 National Employment Action Plan (NEAP), a window of opportunity occasioned by the European Employment Strategy Open Method of Co-ordination, which required each national government to enter into a national policy dialogue and produce a National Employment Action Plan to promote activation and other policy.

While increased links between national and international interests influenced and weakened institutional vetoes on conditionality, there remain institutional vetoes on a stronger model of conditionality which would transform work obligations to lone parents, spouses of male claimants, and people with disabilities. The Department of Social and Family Affairs (DSFA) argues that reluctance to extend conditionality is due to the lack of a coherent childcare infrastructure and of services for people with disabilities ${ }^{75}$. Procrastination may also be due to fear of a political backlash from those who might conservatively respond to measures designed to deny women their 'right' to work in the home. The patriarchal culture may not yet be comfortable with measures to promote women's economic participation. A more recent proposal that all social assistance payments enable a 'lifetime attachment to the labour force' therefore reflects a significant shift in policy consensus. ${ }^{76}$ More recently, DSFA has proposed a practical move from a contingency-structured social security regime to one that identifies claimants by reference to their relationship with the labour market: claimants are young, old or 'working age" 
Again however, despite the rhetoric about reform, there is little evidence of political ambition for such reform.

\section{Defamiliarisation}

The DSFA proposals in 2006 to extend work obligations to lone parents and dependant spouses have potentially far reaching implications; however two years on in 2008 it is not clear that they will be implemented. Despite considerable policy debate there has been little progress towards individualising social security, and Irish social security remains a strong male breadwinner regime in a family-based, gender-differentiated social security system where women experience considerable obstacles to registering as unemployed or accessing labour market supports. Failure to develop a childcare infrastructure remains the biggest obstacle to increased employment participation for women. Reliance on market-led responses to childcare and limiting eldercare responses to tax incentives to provide private nursing homes ${ }^{78}$ is what would be expected more in a competition state than a developmental welfare state.

While the state partially individualised personal tax credits, failure to individualise social security or to introduce child and elder care supports is paradoxical in a competition state aiming to increase the labour force participation of mothers. A neo-liberal fixation on limiting state intervention is a partial explanation but policy inaction or lack of transformation is not just about ideology or cost avoidance. Policy paralysis is due to politicians' fears of introducing reforms in the absence of policy consensus and to the political difficulty of mediating between those advocating conflicting policy options. ${ }^{79}$ Policy is also limited by the strong veto power of employers who resist parental leave policies. The lack of policy to promote women's economic participation is also due to a deeply rooted ideological ambiguity about mothers' labour-market participation in a conservative, patriarchal political culture. ${ }^{80}$ Despite these obstacles women's and especially mothers' labour market participation has increased significantly in Ireland. However, this is not because the state sought to improve women's social rights and quality of life by encouraging and enabling labour market participation; rather until 2006 state action was limited to investment in childcare framed in a narrow productivist policy which aimed to promote parental employment to meet labour market shortages. In no way can the state be described as transformative in relation to women's equality in the labour market or elsewhere.

\section{Globalisation and models of state: evidence}

The survey of the changing nature of Irish social security policy shows that trends have moved in a direction consistent with the competition state indicators but also stresses how political agency and the role played by public and private domestic institutions and practices as well as national and international interest groups help influence policy choices. ${ }^{81}$ Particular policies were mediated through Irish political institutions, ideology and culture. The end result is a particular 'Irish style' recommodification which, while heavily market-oriented, is still somewhat limited in the scale and scope of reforms. Indeed, it is remarkable how closely the Irish state's actions echo Cerny's description of the competition state model as one in which state actors, both politicians and bureaucrats, react to the pressures of the global market by 'promoting the competitive advantages of 
particular production and service sectors in a more open and integrated world economy' ${ }^{82}$ In this situation, state actions 'are often designed to enforce global market rational economic and political behaviour on rigid and inflexible private sector actors as well as on state actors and agencies. The institutions and practices of the state itself are increasingly marketised or "commodified", and the state becomes the spearhead of structural transformation to market norms both at home and abroad'. As a result, 'the actual amount or weight of government imbrication in social life can increase ... at the same time the power of the state to control specific activities and market outcomes continues to diminish' undermining the 'overall strategic and developmental capacity' of state agencies. ${ }^{83}$ Indeed, this situation results in 'the splintering of the state itself' as 'state actors themselves, once said to be "captured" by large, well-organized domestic constituencies, are increasingly captured instead by transnationally-linked sectors which set state agencies against each other as in the desire to "level the playing field" for their domestic clients in the wider world' ${ }^{84}$ Many domestically oriented interest and pressure groups are increasingly marginalised in the formulation of policy while transnationally linked groups not only gain influence but also can play state actors off against one another. Cerny concludes: 'The crucial point ... is that those tasks, roles and activities [of states] will not just be different, but will lose much of the overarching, macro-political character traditionally ascribed to the effective state, the good state or the just state' ${ }^{85}$

The review of the Irish case also highlights the degree to which social policy reform has not been characterised by any transformative developmental logic. Social policy more resembles a frozen landscape of policy reform. A blanket of low taxation shrouds a weak developmental rhetoric coming from certain state departments and policy agencies. At the same time, the state responds quickly to the combined power of private business allied to certain state departments and agencies lobbying for market-based social policy. As NESC and Cousins ${ }^{86}$ conclude, a more transformative social policy capable of translating developmental rhetoric into policy outcomes remains a considerable challenge for the Irish state.

Evans stressed how a coherent encompassing state reconciles conflicting interests through a complex network of ties that bind it to societal allies with transformational goals. Shared vision about collective problems is a fundamental organisational strategy of a developmental welfare state. Cousins and Connolly ${ }^{87}$ conclude however that the Irish state's attempt to manage distributional conflict through governance processes that embed supposed shared transformational goals in the institutional processes of social partnership has actually blocked transformative social policy. They emphasise how embedding the anti-poverty strategy in the macroeconomic policy framework has served to residualise that strategy and conclude that social policy will not be tranformational until there has been a fundamental reworking of the economic strategy underpinning the Irish project.

This review has illustrated how it is not developmental goals but neoliberal commodification that has driven Irish social policy. The state finds globalisation is constraining to the degree that it restricts policy options that require state funding and hence that might require increased taxation. The same can be said of health policy 
(incentivising the market to build private hospitals) education policy (increased resort to fee-paying education, subsidised by the state) and housing policy (the shift from social rental to affordable market homes). The review showed that the state has not withdrawn but has, where politics has allowed it, facilitated market-based responses to social policy. It is questionable whether this can be described as a model of state-led development, rather it is a state acting in new collaborative relationship with global market actors but also seeking to appease the demands and pressures of other domestic actors. The net result in a country with as many domestic vetoes as Ireland is not developmental or transformative but indicates the failure to develop or transform social policy to deliver the institutions and programmes required in an era of globalisation.

The Developmental Welfare State makes the hard 'business case' that a more knowledgebased and innovative economy requires significantly improved social policies. In particular, it argues that much greater investment in families and children, and in the multiple supports that empower people to sustain employment throughout their lives, will be needed if policy is to result in a more inclusive and equal society. This suggests that the transformational or developmental welfare state is not yet performing in social policy at the same capacity as it is in economic policy. Rather there is a need to transform from a 'low road' of passive social policy to a 'high road' of active develomental policy. As Sweeny observes, this entails embracing the deep changes to Ireland's educational and training systems and welfare state that are needed to stem the intergenerational transmission of educational disadvantage, the 'brain waste' of child poverty, the neglect of people with disabilities, the underperformance of ethnic minorities, and the discarding of older workers. ${ }^{88}$ Despite such rhetoric this transformative developmental welfare state is not yet in evidence and rhetoric alone will not produce it.

\section{Conclusions}

This article has examined the changing nature of Irish social security policy in order to test the competing hypotheses of whether the Irish state is a developmental state or a competition state. It has been found that the weight of evidence confirms Ireland as a competition state, though one in which there are some developmental aspirations. In undertaking a detailed study of one policy arena, this paper has moved the study of characterisations of the state out of the ethereal realms of abstraction criticised by Hay and, following Phillips, has devoted attention to variation, contingency and specificity in the institutional structures of the Irish state, the nature of Irish state strategies and the types of state-society linkages that prevail in the contemporary Irish political economy. It has populated the Irish state with clearly identified actors, as sought by Hay. It is hoped therefore that it may open a new phase in debates about how states are adjusting to the pressures of today's globalisation, focusing attention in particular on how these pressures are mediated by institutions, actors and political cultures to account for the varied nature of outcomes observed.

The significance of the choice of Ireland as a case study derives from its emblematic status as a model of developmental success in the era of globalisation. ${ }^{89}$ This article raises questions not only about the limitations of this success but also about its institutional underpinnings. Equally important however are the questions it raises for the 
wider international debates on developmental or competition states. Central to these is the potential for change that exists, as this is a topic on which the theoretical debate lacks clarity as was outlined above. In other words, can a competition state move in a more developmental direction and how might such a move happen? The proposal by some policy makers in the Irish case to move to a developmental welfare state at least shows an awareness of the developmental limitations of the existing Irish state. How this proposal might influence the development of Irish social policy will provide an interesting case study of the possibilities for change or of the solidity of the present model of the competition state.

\footnotetext{
${ }^{1}$ Paul Sweeney, 'Globalisation: Ireland in a Global Context', in Maura Adshead and Michelle Millar (eds), Public Administration and Public Policy in Ireland (Routledge, 2003), pp. 210-18; Frank Barry, 'Future Irish growth: opportunities, catalysts, constraints', ESRI Quarterly Economic Commentary (ESRI, 2005), pp. 34-58.

${ }^{2}$ Frank Barry (ed.), Understanding Ireland's Economic Growth (Macmillan, 1999); Paul Sweeney, The Celtic Tiger: Ireland's Economic Miracle Explained (second edition, Oak Tree Press, 1999); Peter Clinch, Frank Convery, and Brendan Walsh, After the Celtic Tiger: Challenges Ahead (O’Brien Press, 2002).

${ }^{3}$ Brian Nolan, Philip J. O’Connell and Christopher T. Whelan (eds), Bust to Boom? The Irish Experience of Growth and Inequality (IPA, 2000), p. 3.

${ }^{4}$ Ibid., p. 1.

${ }^{5}$ Seán Ó Riain, (2000): 'The Flexible Developmental State: Globalisation, Information Technology and the “Celtic Tiger”', Politics \& Society, Vol. 28, No. 2 (2000), pp. 157-93; Seán Ó Riain, The Politics of HighTech Growth: Developmental Network States in the Global Economy (Cambridge University Press, 2004).

${ }^{6}$ Peadar Kirby, The Celtic Tiger in Distress: Growth with Inequality in Ireland (Palgrave, 2002); Peadar Kirby, 'The Irish State and the Celtic Tiger: A “flexible developmental state" or a competition state?', in: Graham Harrison (ed.), Global Encounters: International Political Economy, Development and Globalisation (Palgrave Macmillan, 2005), pp. 74-94.

${ }^{7}$ Fiona Dukelow, 'The path towards a more "employment friendly" liberal regime?: Globalisation and the Irish social security system', paper presented at the Foundation for International Studies of Social Security Seminar (FISS), Stockholm, June 2004, p. 47.

${ }^{8}$ Nigel Boyle, FÁS and Active Labour Market Policy 1985-2004, Studies in Public Policy: 17, (The Policy Institute, 2005), p. 16.

${ }^{9}$ Nick Bisley, Rethinking Globalization (Palgrave Macmillan, 2007); Philip G. Cerny, 'Restructuring the political arena: Globalization and the paradoxes of the competition state', in Randal D. Germain (ed.), Globalization and its Critics: Perspectives from Political Economy (Macmillan, 2000), pp. 117-38; Bob Jessop, The Future of the Capitalist State (Polity, 2002); Colin Hay, Michael Lester and David Marsh (eds), The State: Theories and Issues (Palgrave Macmillan, 2006); Linda Weiss, The Myth of the Powerless State (Polity, 1998).

${ }^{10}$ Colin Hay, 'Re-stating politics, re-politicising the state: neo-liberalism, economic imperatives and the rise of the competition state', Political Quarterly, Special Issue (2004), pp 38-50: 47.

${ }^{11}$ Nicola Phillips, 'State Debates in International Political Economy' in: Nicola Phillips (ed.), Globalizing International Political Economy (Palgrave Macmillan, 2005), pp. 82-115 (emphasis in original).

${ }^{12}$ It is acknowledged that the concepts of developmental or competition state do not exhaust the possible characterisations that can be made of the state, and that there exist other approaches to characterising the state (such as the varieties of capitalism literature or regulation theory). However, since the purpose of this article is to make a contribution to wider debates through an analysis of the Irish state, and since a debate on the developmental versus competition state concepts has dominated the recent literature on the Irish state, this article limits itself to this debate within international political economy.

${ }^{13}$ Chalmers Johnson, MITI and the Japanese Miracle: The Growth of Industrial Policy, 1925-1975 (Stanford University Press, 1982); Meredith Woo-Cumings (ed.), The Developmental State (Cornell University Press, 1999); Robert Wade, Governing the Market: Economic Theory and the Role of
} 
Government in East Asian Industrialization (Princeton University Press,1990); Alice Amsden, Asia's Next Giant: South Korea and Late Industrialization (Oxford University Press, 1989).

${ }^{14}$ Peter Evans, Embedded Automony: States and Industrial Transformation (Princeton Univeristy Press, 1995).

${ }^{15}$ Ó Riain, 'The Flexible Developmental State' and Ó Riain, The Politics of High-Tech Growth.

${ }^{16}$ Ó Riain, The Politics of High-Tech Growth: Developmental Network States in the Global Economy, p. 4.

${ }^{17}$ NESC (National Economic and Social Council), An Investment in Quality: Services, Inclusion and Enterprise (NESC, 2003), pp. 29-33; NESC, The Developmental Welfare State (NESC, 2005).

${ }^{18}$ Theda Skocpol, 'Bringing the State Back In: Strategies of Analysis in Current Research', in Peter B. Evans, Dieter Reuschemeyer and Theda Skocpol (eds), Bringing the State Back In (Cambridge University Press, 1985), pp. 3-37: 9.

${ }^{19}$ Weiss, The Myth of the Powerless State, p 4.

${ }^{20}$ Quoted in Ibid., p. 10.

${ }^{21}$ Quoted in Richard Breen, Damian F. Hannan, David B. Rottman and Christopher T. Whelan, Understanding Contemporary Ireland: State, Class and Development in the Republic of Ireland (Macmillan, 1990), p. 22.

${ }^{22}$ Ó Riain, The Politics of High-Tech Growth, p. 5

${ }^{23}$ Ibid.

${ }^{24}$ Unevenness is also analysed by Nigel Boyle and Gerry Boucher: 'The Partially Enhanced Institutionalised Capacity of the Irish State: Development planning, infrastructural planning and training policy 1987-2007', paper delivered at the Political Studies Association of Ireland $25^{\text {th }}$ annual conference, $19^{\text {th }}$ to $21^{\text {st }}$ October 2007, Dublin.

${ }^{25}$ Weiss, The Myth of the Powerless State, p 4.

${ }^{26}$ Ibid., p. 12.

${ }^{27}$ Peter A. Hall and David Soskice, 'An Introduction to Varieties of Capitalism', in Peter A. Hall and David Soskice (eds), Varieties of Capitalism: The Institutional Foundations of Comparative Advantage (Oxford University Press, 2001), pp. 1-68.

${ }^{28}$ Christopher Pierson, The Modern State (Routledge, 2004), pp. 100-102.

${ }^{29}$ John Gerard Ruggie, ‘Taking Embedded Liberalism Global: the Corporate Connection’, in David Held and Mathias Koenig-Archibugi (eds), Taming Globalisation: Frontiers of Governance (Polity Press, 2003), pp. 93-129: 94.

${ }^{30}$ Ramesh Mishra, Globalisation and the Welfare State (Edward Elgar, 1999); Fritz W. Scharpf, 'The viability of advanced welfare states in the international economy: vulnerabilities and options', Journal of European Public Policy, Vol. 7, No. 2 (2000), pp. 190-228.

${ }^{31}$ Bob Jessop, 'The Transition to post-Fordism and the Schumpeterian Workfare State' in Roger Burrows and Brian Loader (eds) Towards a Post-Fordist Welfare State? (Routledge, 1994) pp. 13-37: 24.

32 Philip G. Cerny, Georg Menz, and Susanne Soederberg, 'Different Roads to Globalization: Neoliberalism, the Competition State, and Politics in a More Open World' in Susanne Soederberg, Georg Menz and Philip G. Cerny (eds), Internalizing Globalization: The Rise of Neoliberalism and the Decline of National Varieties of Capitalism (Palgrave, 2005), pp. 1-30: 19.

${ }^{33}$ Ibid., pp 22-23.

${ }^{34}$ Ibid., pp. 21-22 (emphasis in original).

${ }^{35}$ Ibid., pp. 11-18 (emphasis in original).

${ }^{36}$ Cerny et al., 'Different Roads to Globalization', p. 20 (emphasis in original).

${ }^{37}$ Ibid., pp 20-21.

${ }^{38}$ Ó Riain, The Politics of High-Tech Growth., p. 18.

${ }^{39}$ Ibid., pp. 237-42.

${ }^{40}$ Ibid., p. 38.

${ }^{41}$ Philip G. Cerny, 'Political Globalization and the Competition State' in: Richard Stubbs and Geoffrey R.D. Underhill (eds), Political Economy and the Changing Global Order (Oxford University Press, 2006), pp. 376-86: 381.

${ }^{42}$ Hay, 'Re-stating politics, re-politicising the state', p. 47.

${ }^{43}$ Phillips, 'State Debates in International Political Economy', p. 110 (emphasis in original).

${ }^{44}$ Evans, Embedded Autonomy, p. 248. 
${ }^{45}$ Cerny, 'Political Globalization and the Competition State', p. 381.

${ }^{46}$ Ibid., p. 382 (emphasis in original).

${ }^{47}$ Cerny et al., 'Different Roads to Globalization', p. 17.

${ }^{48}$ Ibid., p. 17.

${ }^{49}$ Government of Ireland, Programme for Economic and Social Progress (Stationary Office, 1990)

${ }^{50}$ NESC, Developmental Welfare State and National Economic and Social Forum (NESF), Creating a more inclusive labour market, Report No 33 (Stationery Office, 2006).

${ }^{51}$ NESC, Developmental Welfare State, pp. 206-7.

${ }^{52}$ NESC, An Investment in Quality: Services, Inclusion and Enterprise (National Economic and Social Council, 2003).

${ }^{53}$ Jens Alber and Guy Standing, 'Social dumping, Catch up or Convergence, Europe in a Comparative Global Context', Journal of European Social Policy, Vol. 10, No. 2, (2000), pp. 99-119: 99.

${ }^{54}$ Paul Pierson, 'Irresistible Forces, Immovable Objects: Post-industrial welfare states confront permanent austerity', Journal of European Social Policy, Vol. 5, No. 4 (1998), pp. 539-60.

${ }^{55}$ Government of Ireland, Expert Working Group on the Integration of the Tax and Welfare Systems Report (Stationery Office, 1996). NESC, Developmental Welfare State, p. 52 outlines the distributional outcome of this child income-support reform. The value of child income support for higher income groups receiving only universal child benefit payments increased by $173 \%$ over the $1994-2004$ period while low-income families relying on the combined child-dependant allowances and child benefit experienced only a $52 \%$ increase over the same period.

${ }^{56}$ Department of Social Welfare, Securing Retirement Income: National Pensions Policy Initiative (Stationery Office, 1997); Government of Ireland, Final Report of the Benchmarking and Indexation Working Group, Programme for Prosperity and Fairness (Stationery Office, 2001).

${ }^{57}$ Earned income disregards allow claimants disregard a certain amount of earnings from social assistance means tests and are therefore considered an important welfare-to-work incentive.

${ }^{58}$ NESC, Developmental Welfare State, p. xvi.

${ }^{59}$ Alber and Standing, 'Social Dumping, Catch up or Convergence', p. 101.

${ }^{60}$ This represents a significant policy shift from the 1986 Commission on Social Welfare consensus recommendation to expand social insurance coverage and reduce the use of social assistance payments.

${ }^{61}$ Benefit dependency rose from $12.4 \%$ in 1980 to hold constant at $20 \%$ for claimants (37\% for all adult and child recipients) over 1985-2005.

${ }^{62}$ NESC, Developmental Welfare State.

${ }^{63}$ Social welfare increases fell considerably below net increases in earnings over the 1991-2001 period with the long-term unemployment assistance payment increasing by 64\% compared to net average industrial earnings increasing by $109.1 \%$ (Final Report of the Benchmarking and Indexation Working Group, p. 46, Table 6.6).

${ }^{64}$ Eurostat, European Social Statistics Social Protection Expenditure and Receipts 1991-2000 (Eurostat, 2003) Eurostat, Statistics in Focus (Eurostat, various years).

${ }^{65}$ Christopher T. Whelan and Richard Layte, 'Opportunities for All in the New Ireland?', in Tony Fahey, Helen Russell and Christopher T. Whelan (eds), Best of Times? The Social Impact of the Celtic Tiger (Institute of Public Administration, 2007), pp. 67-85: 68.

${ }^{66}$ Central Statistics Office, Measuring Ireland's Progress, 2004 (Stationery Office, 2005).

${ }^{67}$ While fewer people were unemployed, the risk of poverty for those remaining unemployed doubled from 23.9\% in 1994 to $43.1 \%$ in 2001, while for older people the risk increased from $5.3 \%$ in 1994 to $49 \%$ in 2001 (C.T. Whelan, R. Layte, B. Maitre, B. Gannon, B. Nolan, D. Watson and J. Williams, Monitoring Poverty Trends in Ireland: Results from the 2001 Living in Ireland Survey, Policy Research Series No 51 (ESRI, 2003), Table 4.22.

68 Government of Ireland, Sharing in Progress: National Anti-Poverty Strategy (Stationery Office, 1997).

69 Anthony McCashin, Social Security in Ireland (Gill and Macmillan, 2004), p. 211; Dukelow, 'The path towards a more “employment friendly” liberal regime?', pp. 16-18.

${ }^{70}$ As a high net recipient of EU Structural funds, Ireland was required to spend on active labour-market policies.

${ }_{71}^{71}$ Mel Cousins, Explaining the Irish Welfare State (Edwin and Mellor, 2005).

${ }^{72}$ Boyle, FÁS and Active Labour Market Policy 1985-2004. 
${ }^{73}$ McCashin Social Security in Ireland, p. 220; W. Van Oorschot, 'Miracle or Nightmare? A Critical Review of Dutch Activation Policies and their Outcomes', Journal of Social Policy, Vol. 31, No. 3, (2002), pp. 399-420; Boyle, FÁS and Active Labour Market Policy 1985-2004, p. 59; Seán Ó Riain and Philip O'Connell, 'The role of the state in growth and welfare' in Brian Nolan, Philip J. O'Connell and Christopher T. Whelan (eds), Bust to Boom? The Irish Experience of Growth and Inequality (IPA, 2000), pp. 310-39; Mary Daly and Nicola Yeates, 'Common Origins, Different Paths', Policy and Politics, Vol. 31 No. 1 (2003), pp. 86-97: 94; John Martin and David Grubb, What works and for whom: A review of OECD countries' experiences with active labour market policies, Office of Labour Market Policy Evaluation Working Paper (2001), p. 14.; Mark Pearson, 'Targeting social expenditure', discussion paper to Combat Poverty Agency Social Expenditure Conference, $16^{\text {th }}$ September 2003.

${ }^{74}$ George Taylor, 'Hailing with an Invisible Hand: Neoliberal Politics in Ireland', Government and Opposition, Vol. 37, No. 4 (2002), pp. 501-523; Dukelow, 'The path towards a more "employment friendly” liberal regime?', p. 22. Up to 40 significant punitive or supportive changes took place over the period 1986-2005, some of which had a substantial impact on the quality of social protection experienced by the claimant. Negative changes included freezing child-income support, limiting duration of payments, means-testing insurance payments, and restricting part-time workers' access to insurance payments.

${ }^{75}$ Department of Social and Family Affairs, Review of One Parent Family Payment, Programme Evaluation Report No. 7 (Stationery Office, 2000). Department of Social and Family Affairs, Report of the Review of Illness and Disability Payments (Stationery Office, 2003).

${ }^{76}$ NESC, Developmental Welfare State, p. 178.

${ }^{77}$ DSFA, Proposals for supporting Lone Parents: Government Discussion Paper, (Stationery Office, 2006) has important gender implications as it places all means-tested working-age mothers, who depend on social welfare on an employability continuum.

${ }^{78}$ Government of Ireland, National Development Plan 2000-2006 (Stationery Office, 2000).

${ }^{79}$ Pat Montague, Persuasive Influence, An assessment of how Irish groups campaign around the budget, unpublished MA thesis, Dublin City University (2001) describes three key policy coalitions comprised of the trade union SIPTU and the IBEC employers' confederation lobbying for tax relief, the Open Your Eyes to Child Poverty Initiative lobbying for child benefit increases, a Childcare 2000 campaign lobbying for a parental childcare payment, and 'Women in the Home', a lobby group campaigning against tax relief. ${ }^{80}$ Eithne McLaughlin, Nicola Yeates and G. Kelly, Units of Assessment: Issues and Options, A report prepared for the Trades Union Congress, November 2001.

${ }^{81}$ Ibid., pp. 19-20.

${ }^{82}$ Philip G. Cerny, 'Structuring the political arena: Public goods, state and governance in a globalising world', in Ronen Palen, Global Political Economy: Contemporary Theories (Routledge, 2000), pp. 21-35: 23.

${ }^{83}$ Cerny, 'Structuring the political arena', pp. 30-34 (emphasis in original).

${ }^{84}$ Philip G. Cerny, 'Globalization at the Micro Level: The Uneven Pluralization of World Politics', Manchester Papers in Politics: CIP Series 5/2002, Manchester: Centre for International Politics,

(Department of Government, University of Manchester, 2002), p. 11.

${ }^{85}$ Cerny, 'Structuring the political arena', p. 23.

${ }^{86}$ NESC, Developmental Welfare State, and Mel Cousins, 'Developing an inclusive society: The way forward', in Mel Cousins (ed.), Welfare Policy and Poverty (Combat Poverty Agency, 2007), pp. 293-324.

${ }^{87}$ Cousins, 'Developing an inclusive society', and Eileen Connolly, The Institutionalisation of Anti-Poverty and Social Exclusion Policy in Irish Social Partnership. Research Working Paper 07/01 (2007), Combat Poverty Agency.

${ }^{88}$ John Sweeney, 'Tackling inequality and social inclusion in a full employment era', paper to Realising Equality and Inclusion: Building better policy and practice, Pobal Conference, Croke Park, Dublin, November $22^{\text {nd }} 2007$.

${ }^{89}$ See for example Eva Paus, Foreign Investment, Development, and Globalization: Can Costa Rica Become Ireland? (Palgrave Macmillan, 2005) and Ruth Rios-Morales and David T. O’Donovan, 'Can the Latin American and Caribbean countries emulate the Irish model of FDI attraction?', CEPAL Review, No 88, (2006), pp. 49-66. 